J. Clin. Chem. Clin. Biochem.

Vol. 28, 1990, pp. 825-833

(C) 1990 Walter de Gruyter \& Co. Berlin $\cdot$ New York

\title{
Analyses with the KODAK-Ektachem. Accuracy Control Using Reference Method Values and the Influence of Protein Concentration
}

\author{
Part I. Electrolytes
}

By W. R. Külpmann, P. Maibaum and O. Sonntag

Institut für Klinische Chemie I, Medizinische Hochschule Hannover

(Received March 14/June 26, 1990)

Summary: The reliability of electrolyte determinations with the Ektachem 700 was evaluated by various means including the use of reference method values. The influence of protein concentration, which may alter the viscosity and hence the speed of diffusion, was systematically investigated by using samples of varying protein concentration obtained by ultracentrifugation.

Calcium. The mean bias between Ektachem results and reference method values of 9 control sera was $-7.3 \%$. In a comparative study with native sera a negative bias was not obtained. The accuracy was independent of the protein concentration.

Chloride. The mean bias was $-0.1 \%$, compared with reference method values. As might be expected, the difference between chloride values with Ektachem - using a "direct" ion-selective electrode - and determinations by coulometry increased with increasing protein concentrations.

Magnesium. A negative bias $(-5.0 \%)$ was obtained in accuracy control with reference method values, and to a smaller extent in a comparative study with native sera. An influence of the protein concentration on the magnesium determination was not observed.

Phosphate. Accuracy control by method-dependent assigned values and a comparative study with native sera showed a positive bias. Ektachem results depend on the protein concentration. At $120 \mathrm{~g} / 1$ protein the bias was $+13.6 \%$.

Potassium. The mean bias, with respect to reference method values, was $-1.2 \%$. At high concentrations of proteins of "normal" composition, Ektachem results agree with measurements by flame atomic emission spectrometry; in paraproteinaemic sera the values are higher.

Sodium. The mean inaccuracy was $3.3 \%$, compared with reference method values. The dependence on the amount and composition of the total protein was similar to that found for potassium analysis.

\section{Introduction}

The advantages of multicentre evaluations of clinical chemical analysers are unquestioned. However, the introduction of fundamentally new principles of determination may increase the importance of some aspects that are ignored or treated only briefly in evaluation protocols based on established methodologies. Therefore, in addition to the general evaluation of the Ektachem system, this study was especially concerned with the possible influence of the protein concentration, which has not yet been systematically investigated. 
In the new concept of quality assessment in the clinical laboratory (1) the evaluation of accuracy has to be performed - if possible - by comparison of the result with the reference method value. Reference method values were used to determine whether the KODAK Ektachem system meets the requirements for accuracy, or whether the results deviate, due to e.g. the matrix of the control sera.

\section{Materials and Methods}

\section{Methods}

\section{Calcium}

1. Ektachem slide (KODAK, Stuttgart, F. R. G.). A spreading layer, dye-mordant layer, buffer layer, and base layer are held on a polyester film support. After application of the serum sample to the slide, the bound calcium is dissociated from binding proteins and migrates into the dye-mordant layer. The indicator dye, arsenazo III, forms a complex with the calcium, which causes a shift in its absorption maximum. Measurement is performed at $680 \mathrm{~nm}$ with reflected light.

2. Flame atomic absorption spectrometry. A flame atomic absorption spectrometer model 3030 Perkin-Elmer (Bodenseewerk Perkin-Elmer, Überlingen, F. R. G.) was used and operated at $422.7 \mathrm{~nm}$ in the double beam mode. Lanthanum chloride $\left(\mathrm{LaCl}_{3}\right.$ - $7 \mathrm{H}_{2} \mathrm{O}$ ) solution was added to the samples to prevent interference by phosphate.

3. Absorption spectrometry. In the comparative study with native sera, calcium determinations were performed by SMAC (Sequential Multiple Analysis plus Computer, Technicon, Bad Vilbel, F. R. G.). Protein-bound calcium is dissociated by hydrochloric acid and forms a complex with cresolphthalein complexone. Magnesium is bound by 8 -hydroxyquinoline.

\section{Chloride}

1. Ektachem slide (KODAK, Stuttgart, F. R. G.). Ion-selective electrodes are used for potentiometric measurement of ionic chloride. The chloride ions in the reference and sample fluid migrate to the silver/silver chloride layers and affect the equilibrium between free chloride and chloride bound to silver ions.

2. Absorption spectrometry. In the comparative study with native sera, chloride was determined by SMA-C (Technicon, Bad Vilbel, F. R. G.). Chloride ions displace thiocyanate from mercuric thiocyanate. Liberated thiocyanate ions react with ferric ions from ferric nitrate to form the red coloured ferric thiocyanate.

3. Coulometry. In the studies on the influence of protein, chloride was determined by coulometry (Chloridmeter 6610, Eppendorf, Hamburg, F. R. G.).

\section{Magnesium}

1. Ektachem slide (KODAK, Stuttgart, F. R. G.). A spreading layer, three reagent layers and a basis layer are fixed on the film support. Magnesium is dissociated from binding proteins and reacts with the indicator dye 5-bis(2-hydroxy-3,5-dichlorphenyl)-3-cyanoformazan (wavelength: $630 \mathrm{~nm}$ ). Calcium is bound to a chelating agent to prevent interference.

2. Flame atomic absorption spectrometry. Magnesium determinations were performed using a flame atomic absorption spectrometer model 3030 Perkin-Elmer (Bodenseewerk Perkin-
Elmer, Überlingen, F. R. G.) operated at $285.2 \mathrm{~nm}$ in the double beam mode. Lanthanum chloride $\left(\mathrm{LaCl}_{3} \cdot 7 \mathrm{H}_{2} \mathrm{O}\right)$ solution was added to the samples to prevent interference by phosphate.

\section{Phosphate, inorganic}

1. Ektachem slide (KODAK, Stuttgart, F. R. G.). A spreading layer, reducing layer, and a molybdate layer are held on a film support. After application, the sample is distributed evenly in the spreading layer. Phosphorus forms a complex with ammonium molybdate, which is reduced by $p$-methylaminophenol sulphate (wavelength: $680 \mathrm{~nm}$ ).

2. Absorption spectrometry.

a) The native sera of the comparative study were analysed by SMA-C (Technicon, Bad Vilbel, F. R. G.) by reaction of the dialysed sample with ammonium molybdate (without reducing agent).

b) Phosphate determinations with the Hitachi 704 (Boehringer Mannheim, Mannheim, F.R.G.) were performed kinetically by use of a modified molybdatophosphate reaction (12).

\section{Potassium}

1. Ektachem slide (KODAK, Stuttgart, F. R. G.). Ion-selective electrodes are used for potentiometric measurement of ionic potassium. The ion-selective membrane is composed of valinomycin dissolved in a polymer mixture.

2. Ion-selective electrode ("indirect" potentiometry). After predilution of the sample, potassium was determined with an ionselective electrode (SMA-C, Technicon, Bad Vilbel, F. R. G.).

\section{Sodium}

1. Ektachem slide (KODAK, Stuttgart, F. R. G.). Sodium is determined potentiometrically with ion-selective electrodes. The ion-selective membrane contains a sodium ionophore, methyl monensin dissolved in a carrier solvent, and a polymeric binder.

2. Ion-selective electrode ("indirect" potentiometry). See Potassium.

\section{Calibration}

For all analytes, the Ektachem 700 was calibrated according to the recommendations of the manufacturer. For the determination of chloride, potassium and sodium, the reference solution GEN OO was used.

\section{Sample preparation}

Samples containing different amounts of protein were prepared as follows.

A homogeneous serum pool $(100 \mathrm{ml})$ was obtained by thoroughly mixing sera from 50 healthy blood donors, using a stirrer and a magnetic rod. It was adjusted to $\mathrm{pH} 7.4$ by addition of glacial acetic acid p. a. (Merck, Darmstadt, F. R. G.). Pool serum $(8 \mathrm{ml})$ was pipetted into each of 10 polycarbonate ultracentrifuge tubes (Beckman, München, F. R. G.). The samples were centrifuged in a Beckman ultracentrifuge L8-80M (Beckman, München, F. R. G.) at $106000 \mathrm{~g}$ for $24 \mathrm{~h}$ at $24^{\circ} \mathrm{C}$.

The sample with the highest protein concentration was obtained by removing the protein-free supernatant completely; samples with lower protein content were obtained by only partly discarding the supernatant; a low protein content was obtained by addition of supernatant to the original serum pool. All prepared samples were thoroughly homogenized. A second serum pool $(100 \mathrm{ml})$, obtained by mixing sera from 50 patients suffering from gammopathies, was treated similarly. 


\section{Quality assessment}

Accuracy control of the calcium, chloride, magnesium, potassium and sodium determinations was performed by comparison with reference method values, which were determined by the authors using published methods. References are given in the tables. Phosphate values for control sera obtained with Ektachem were compared with the mean of the pertinent assigned values of field methods, because reference method values are not available.

\section{Statistics}

In the comparative study (tab. 3) the standardized principal component analysis was used. The lines in the figures were constructed by linear regression analysis.

Tab. 1. Imprecision between days of the Ektachem 700

\begin{tabular}{|c|c|c|c|c|}
\hline Analyte & $\begin{array}{l}\text { Num- } \\
\text { ber of } \\
\text { deter- } \\
\text { mina- } \\
\text { tions }\end{array}$ & $\begin{array}{l}\text { Mean } \\
\text { value } \\
\overline{\mathrm{x}} \mathrm{mmol} / \mathrm{l}\end{array}$ & $\begin{array}{l}\text { Relative } \\
\text { standard } \\
\text { deviation } \\
\text { CV \% }\end{array}$ & $\begin{array}{l}\text { Allowable } \\
\text { relative } \\
\text { standard } \\
\text { deviation }^{5} \text { ) } \\
\%\end{array}$ \\
\hline Calcium & $\begin{array}{l}10 \\
10\end{array}$ & $\begin{array}{c}\left.2.18^{3}\right) \\
\left.3.04^{4}\right)\end{array}$ & $\begin{array}{l}\left.1.0^{3}\right) \\
\left.1.3^{4}\right)\end{array}$ & $\leq 3.3$ \\
\hline Chloride & $\begin{array}{l}10 \\
10\end{array}$ & $\begin{array}{rr}75 & 1 \\
121 & 2\end{array}$ & $\begin{array}{l}\left.1.4^{1}\right) \\
\left.0.8^{2}\right)\end{array}$ & $\leq 2.0$ \\
\hline Magnesium & $\begin{array}{l}10 \\
10\end{array}$ & $\begin{array}{l}\left.1.57^{1}\right) \\
\left.1.63^{2}\right)\end{array}$ & $\begin{array}{l}\left.2.1^{1}\right) \\
\left.1.0^{2}\right)\end{array}$ & $\leq 4.0$ \\
\hline Phosphate & $\begin{array}{l}10 \\
10\end{array}$ & $\begin{array}{l}\left.1.73^{3}\right) \\
\left.2.95^{4}\right)\end{array}$ & $\begin{array}{l}\left.1.7^{3}\right) \\
\left.1.7^{4}\right)\end{array}$ & $\leq 5.0$ \\
\hline Potassium & $\begin{array}{l}10 \\
10\end{array}$ & $\begin{array}{l}\left.2.9^{1}\right) \\
\left.5.6^{2}\right)\end{array}$ & $\begin{array}{l}\left.1.5^{1}\right) \\
\left.0.0^{2}\right)\end{array}$ & $\leq 2.7$ \\
\hline Sodium & $\begin{array}{l}10 \\
10\end{array}$ & $\left.\begin{array}{ll}120 & 1 \\
160 & 2\end{array}\right)$ & $\begin{array}{l}\left.0.6^{1}\right) \\
\left.0.6^{2}\right)\end{array}$ & $\leq 2.0$ \\
\hline
\end{tabular}

1) as determined by use of Kodatrol Level I

${ }^{2}$ ) as determined by use of Kodatrol Level II

${ }^{3}$ ) as determined by use of Kontrollogen L (Behring, Frankfurt, F. R. G.)

$\left.{ }^{4}\right)$ as determined by use of Kontrollogen LP (Behring, Frankfurt, F.R.G.)

${ }^{5}$ ) according to the new guidelines of quality assessment (1)

\section{Results}

\section{Electrolytes}

\section{Calcium}

The imprecision between days was smaller than the allowable relative standard deviation (1) (tab. 1). The results differed by $-7.3 \%$ (tab. 2) from the reference method values. In two out of 9 , the bias exceeded the allowable limits of deviation of $\pm 10 \%$ (1). Values obtained with the Ektachem for 132 patient sera were, however, in satisfactory agreement with the method used for comparison (tab. 3). The mean value from the Ektachem deviated by $+1.3 \%$. According to the results of determinations at different protein concentrations (figs. $1 \& 2$ ) one may conclude that the accuracy of the Ektachem results is independent of the concentration and composition of the proteins.

Tab. 2. Calcium

\begin{tabular}{lll}
\hline Control serum $\left.^{2}\right)$ & $\begin{array}{l}\text { Reference } \\
\text { method value }\end{array}$ & $\mathrm{d} \mathrm{\%}{ }^{3}$ ) \\
mmol/1 & \\
\hline $\mathrm{D}$ & 2.13 & -8.5 \\
$\mathrm{E}$ & 2.18 & -13.3 \\
$\mathrm{H}$ & 2.18 & -6.4 \\
$\mathrm{C}$ & 2.25 & -2.9 \\
$\mathrm{~K}$ & 2.25 & -4.5 \\
$\mathrm{~B}$ & 2.80 & -10.9 \\
$\mathrm{~F}$ & 3.00 & -9.0 \\
$\mathrm{~A}$ & 3.02 & -4.2 \\
$\mathrm{G}$ & 3.05 & -6.2 \\
\hline
\end{tabular}

') Deviation of the value obtained by Ektachem from the reference method value in $\%$.

${ }^{2}$ ) Control serum A: SRM 909 (National Institute of Standards and Technology, Washington, D.C.).

$\mathrm{B}$ to $\mathrm{K}$ : not yet commercially available.

${ }^{3}$ ) Reference method value as determined by the reference method (l.c. $(5,6))$.

Tab. 3. Comparison of results obtained by Ektachem 700 and field methods

\begin{tabular}{|c|c|c|c|c|c|c|c|c|c|}
\hline \multirow[t]{2}{*}{ Quantity } & & \multirow{2}{*}{$\begin{array}{l}\text { Number } \\
\text { of deter- } \\
\text { minations }\end{array}$} & \multicolumn{2}{|c|}{$\begin{array}{l}\text { Standardized principal } \\
\text { component analysis }\end{array}$} & \multirow[t]{2}{*}{$\left.s_{y \cdot x^{1}}{ }^{1}\right)$} & \multirow[t]{2}{*}{$\left.\bar{y}^{2}\right)$} & \multirow[t]{2}{*}{$\left.\overline{\mathrm{x}}^{3}\right)$} & \multirow[t]{2}{*}{$\left.t^{4}\right)$} & \multirow[t]{2}{*}{$\left.r^{5}\right)$} \\
\hline & & & Slope & Intercept & & & & & \\
\hline S-Calcium & $\mathrm{mmol} / \mathrm{l}$ & 132 & 1.007 & 0.02 & 0.05 & 2.26 & 2.23 & $\left.6.3^{6}\right)$ & 0.935 \\
\hline S-Chloride & $\mathrm{mmol} / \mathrm{l}$ & 133 & 0.976 & 3.82 & 2.4 & 104.7 & 103.3 & $\left.4.5^{6}\right)$ & 0.804 \\
\hline S-Magnesium & $\mathrm{mmol} / \mathrm{l}$ & 133 & 0.979 & 0.01 & 0.04 & 0.84 & 0.85 & 1.5 & 0.971 \\
\hline S-Phosphate & $\mathrm{mmol} / \mathrm{l}$ & 59 & 1.026 & 0.00 & 0.03 & 1.21 & 1.18 & $\left.6.4^{6}\right)$ & 0.993 \\
\hline S-Potassium & $\mathrm{mmol} / \mathrm{l}$ & 106 & 1.003 & 0.00 & 0.07 & 4.37 & 4.35 & 1.6 & 0.989 \\
\hline S-Sodium & $\mathrm{mmol} / \mathrm{l}$ & 123 & 1.085 & -10.02 & 2.2 & 139.3 & 137.7 & $\left.6.18^{6}\right)$ & 0.838 \\
\hline
\end{tabular}

\footnotetext{
1) standard error of residuals

${ }^{2}$ ) arithmetic mean of results obtained by Ektachem 700

${ }^{3}$ ) arithmetic mean of results obtained by field method

${ }^{4}$ ) t-value (paired t-test)

5) correlation coefficient

$\left.{ }^{6}\right)$ statistically significant $(\alpha<0.01)$
} 


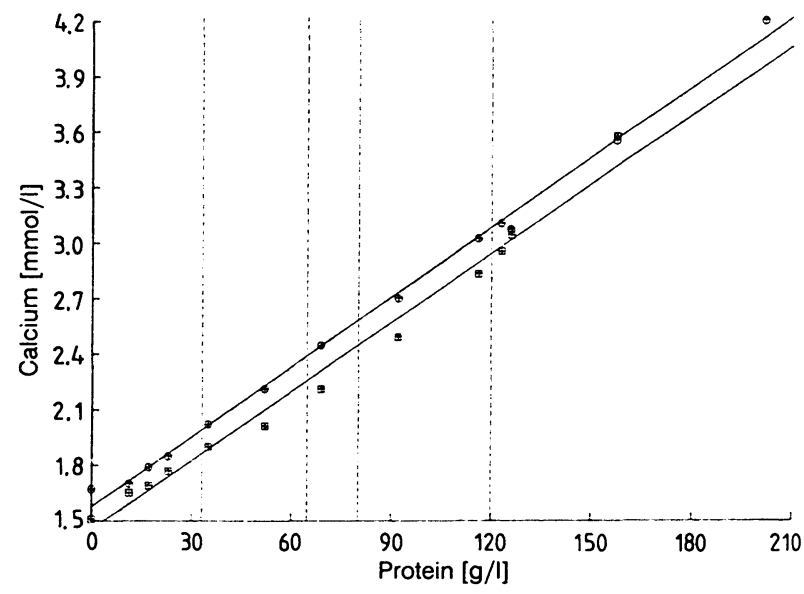

Fig. 1. Determination of calcium in serum preparations $(\mathrm{pH}$ 7.41) of different protein concentrations (prepared by ultracentrifugation, see "Methods") by flame atomic absorption spectrometry $(\oplus)$ and with the Ektachem $700(\boxplus)$. The reference interval of total protein (65$80 \mathrm{~g} / \mathrm{l})$ and of the extreme concentrations found in every thousandth patient according to our files, are shown by the dotted line. Evaluation by linear regression analysis.

\section{Chloride}

Although the requirements of the guidelines for precision are rather stringent, they were met by the Ektachem 700 (tab. 1). Accuracy was much better than that reported in a previous study with the Ektachem DT 60 (2) (tab. 4). The mean bias was $-0.1 \%$ and all results were within the limits of $\pm 6 \%$ (1). With respect to native sera, the results with the Ektachem were in acceptable agreement with those from the comparative method, even though the mean values differed significantly by $1.4 \mathrm{mmol} / 1(-1.3 \%)$ (tab. 3). From measurements with native sera (figs. $3 \& 4$ ) and from experiments with centrifuged sera (1.c. (2)) it is evident that the chloride values with the Ektachem

Tab. 4. Chloride

\begin{tabular}{lll}
\hline Control serum $^{2}$ ) & $\begin{array}{l}\text { Reference } \\
\text { method value }\end{array}$ & $\left.\mathrm{d} \%^{1}\right)$ \\
mmol/1 & \\
\hline $\mathrm{C}$ & 98.9 & +1.1 \\
$\mathrm{E}$ & 99.0 & +1.0 \\
$\mathrm{D}$ & 99.2 & +1.8 \\
$\mathrm{~B}$ & 103.2 & +3.7 \\
$\mathrm{~A}$ & 108.0 & -3.7 \\
$\mathrm{~K}$ & 109.4 & -5.0 \\
$\mathrm{~F}$ & 114.3 & +3.2 \\
$\mathrm{H}$ & 114.8 & -3.7 \\
$\mathrm{G}$ & 116.2 & +0.7 \\
\hline
\end{tabular}

1) Deviation of the value obtained by Ektachem from the reference method value in \%.

${ }^{2}$ ) Control serum A: SRM 909 (National Institute of Standards and Technology, Washington, D. C.).

$\mathrm{B}$ to $\mathrm{K}$ : not yet commercially available.

$\left.{ }^{3}\right)$ Reference method value as determined by the reference method (1.c. 7).

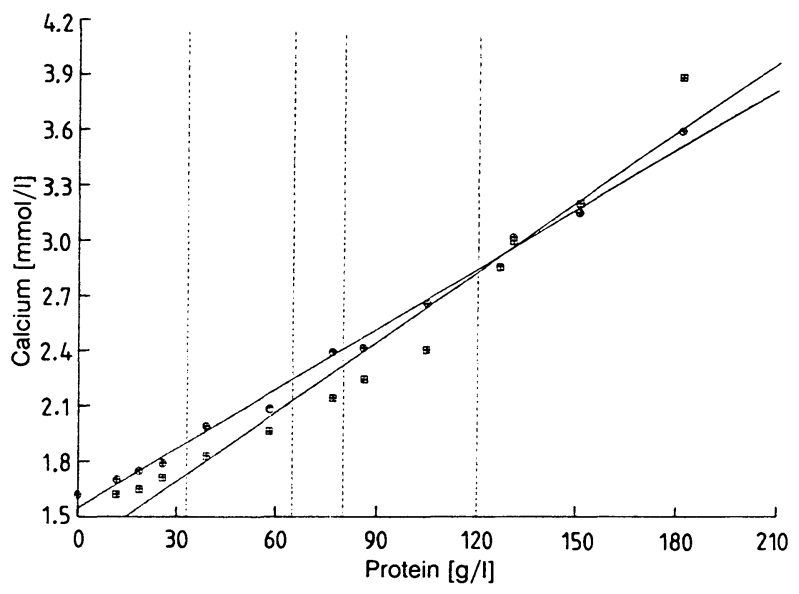

Fig. 2. Determination of calcium in preparations of paraproteinaemic sera ( $\mathrm{pH}$ 7.39) of different protein concentrations (prepared by ultracentrifugation, see "Methods") by flame atomic absorption spectrometry $(\oplus)$ and with the Ektachem 700 ( $⿴ 囗 十)$. Dotted line: see fig. 1. Evaluation by linear regression analysis.

are higher than those obtained by coulometry at high protein concentrations. At low protein concentrations, the chloride results with the Ektachem were lower than those obtained by coulometry. This is to be expected, when measurements are performed by "direct" ion-selective electrodes, which are calibrated by sera with a "normal" protein concentration. At 33 $\mathrm{g} / 1$ protein, the Ektachem results were $3.2 \%$ lower and at $120 \mathrm{~g} / \mathrm{l}$ protein $10.9 \%$ higher than the results by coulometry. Paraproteinaemic sera did not appear to behave differently from sera with "normal" protein composition, but this is not conclusive, because a "direct" ion-selective electrode was not available for comparison.

Tab. 5. Magnesium

\begin{tabular}{lll}
\hline Control serum $\left.{ }^{2}\right)$ & $\begin{array}{l}\text { Reference } \\
\text { method value }\end{array}$ & $\mathrm{d} \mathrm{\%}{ }^{3}$ ) \\
mmol/1 & \\
\hline E & 0.82 & -4.9 \\
K & 0.85 & -9.4 \\
D & 0.86 & -6.4 \\
C & 0.92 & -2.2 \\
H & 0.97 & -8.3 \\
A & 1.21 & -2.6 \\
G & 1.49 & -1.4 \\
\hline
\end{tabular}

1) Deviation of the value obtained by Ektachem from the reference method value in $\%$.

${ }^{2}$ ) Control serum A: SRM 909 (National Institute of Standards and Technology, Washington, D. C.).

$\mathrm{C}$ to $\mathrm{K}$ : not yet commercially available.

$\left.{ }^{3}\right)$ Reference method value as determined by the reference method (1.c. 8). 


\title{
Biochemistry of Peptide Antibiotics
}

\section{Recent Advances in the Biotechnology of $\beta$-Lactams and Microbial Bioactive Peptides}

\author{
Editors: Horst Kleinkauf, Hans von Döhren
}

$1990.17 \mathrm{~cm} \times 24 \mathrm{~cm}$. XIV, 522 pages. With numerous illustrations. Hardcover. DM 310,-; approx. US \$ 182.00 ISBN 3110119285

Peptide Antibiotics, $\beta$-Lactams and bioactive Peptides have maintained a significant position in research and applications. Classical Cyclopeptides like Gramicidin S, Cyclosporin, Bleomycins, the various Proteinase Inhibitors, Siderophores, new $\beta$-Lactams and Vancomycin type Glycopeptides are presented from their representative leads in basic research in biosynthesis, genetics, chemistry, pharmacology, and biotechnology. The main developments of the last years have been reviewed, and structural information on naturally occurring Peptides has been compiled.

This monograph will serve researchers in the Peptide field as source and reference book.

\section{From the Contents}

Bioactive Peptides - Recent Advances and Trends - Gramicidin S Synthetase - Formation on $N$ methylated Peptide Bonds in Peptides and Peptidols - Peptide Bond Synthesis by Enzyme-Catalyzed Acyl-Transfer - Genetics of Siderophore Biosynthesis and Transport - Discovery of new $\beta$-Lactam and $\beta$-Lactam like Antibiotics from Bacteria $\cdot$ Glycopeptide Antibiotics of the Vancomycin Group - Peptide Phytotoxins from Plant Pathogenic Fungi - Chemical Synthesis and Bioactivity of Gramicidin S and Related Peptides - Cyclosporine: Synthetic Studies, StructureActivity Relationships, Biosynthesis and Mode of Action - Biosynthesis and Chemical Synthesis of Bleomycin - Small Molecular Protease Inhibitors and Their Biological Effects - Directed Biosynthesis of Neoviridogriseins - Biochemical Genetical and Biotechnical Aspects of Antibiotic Production via Immobilised Biocatalysis - Compilation of Peptide Structures - A Biogenetic Approach · Contributors · Index

Price is subject to change without notice 


\section{Peptides 1988}

\section{Proceedings of the 20th European Peptide Symposium}

September 4-9, 1988 - University of Tübingen

Tibingen, Federal Republic of Germany

1989. $17 \times 24 \mathrm{~cm}$. LX, 795 pages. With numerous illustrations.

Hardcover. DM 386,-; approx. US \$193.00 ISBN 3110109492

The development of peptide chemistry and its increased importance in various fields of biochemistry, biology and medicine has been well documented in the Proceedings of the European Peptide Symposia.

Peptides 1988 presents contributions from scientists all over the world to the 20th Peptide Symposium.

\section{From the Contents}

Methodology of Synthesis - Peptides with Unusual and Modified Residues - Physical Studies on Peptides - Hormones, Receptors and Structure-Activity Relationships · Immunochemistry $\cdot$ Author Index $\cdot$ Subject Index

Also available:

\section{Peptides 1982}

Editors Blàha, Malǒn

1983. $17 \mathrm{~cm} \times 24 \mathrm{~cm}$. LVI, 846 pages. DM 280,- ISBN 3110095742

\section{Peptides 1986}

Editor Theodoropoulos

1987. $17 \mathrm{~cm} \times 24 \mathrm{~cm}$. XIX, 684 pages. DM 320,- ISBN 3110106876 


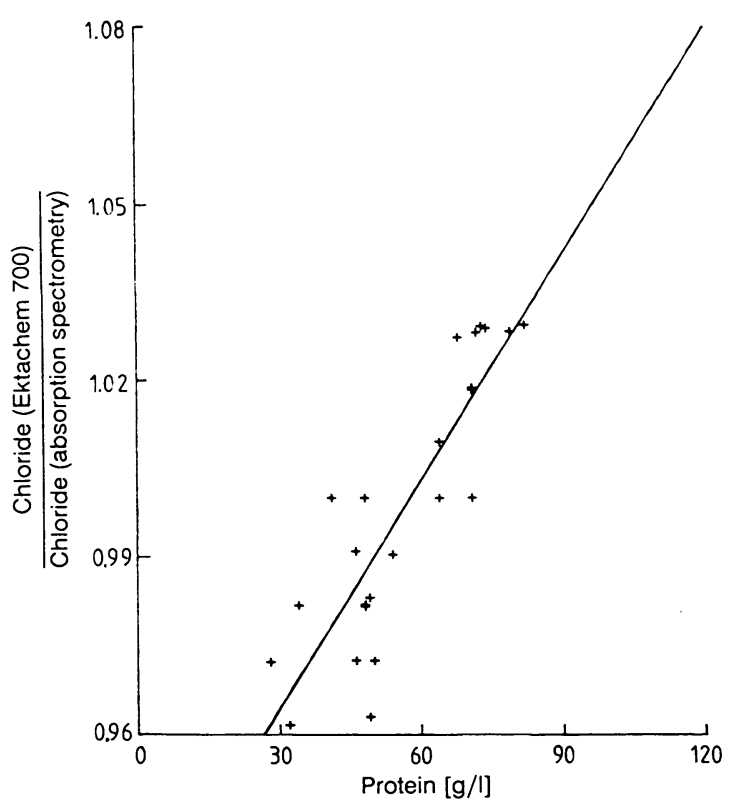

Fig. 3. Determination of chloride in samples of native sera with the Ektachem 700 and by absorption spectrometry in relation to the protein concentration $(n=24)$. Evaluation by linear regression analysis.

\section{Magnesium}

Imprecision was almost half of the requirements of the guidelines (1). Mean deviation from the reference method values was $-5.0 \%$ (tab. 5), but the maximal deviation was always less than $\pm 12 \%$ (1). A systematic (proportional) error was not evident, when native

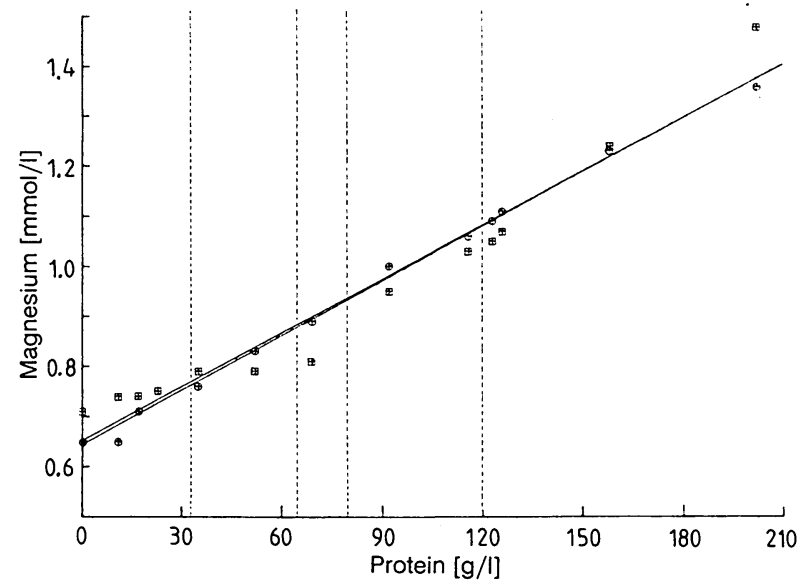

Fig. 5. Determination of magnesium in serum preparations $(\mathrm{pH}$ 7.41) of different protein concentrations (prepared by ultracentrifugation, see "Methods") by flame atomic absorption spectrometry $(\oplus)$ and with the Ektachem $700(\boxplus)$. Dotted line: see fig. 1 . Evaluation by linear regression analysis.

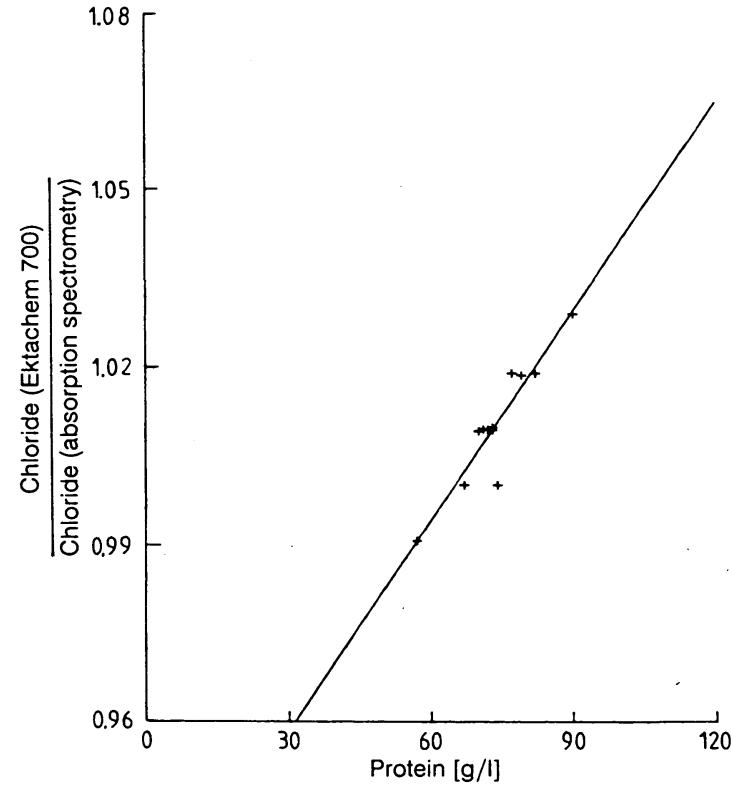

Fig. 4. Determination of chloride in samples of native paraproteinaemic sera with the Ektachem 700 and by absorption spectrometry in relation to the protein concentration $(n=12)$. Evaluation by linear regression analysis.

sera were analysed (tab. 3). An influence of protein on the magnesium results was not observed. At high and low concentrations of "normal" proteins and of paraproteins, there was good agreement between the results with the Ektachem and by flame atomic absorption spectrometry (figs. $5 \& 6$ ).

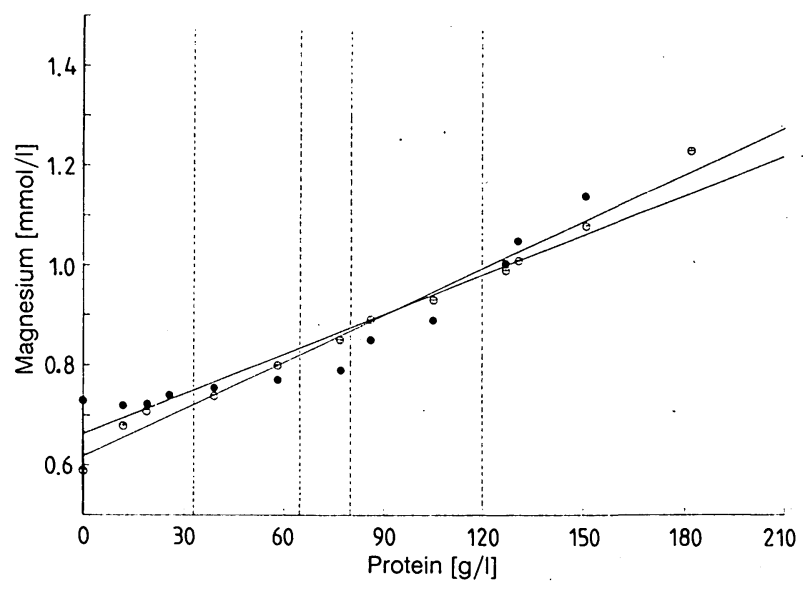

Fig. 6. Determination of magnesium in preparations of paraproteinaemic sera ( $\mathrm{pH}$ 7.39) of different protein concentrations (prepared by ultracentrifugation, see "Methods") by flame atomic absorption spectrometry $(\oplus)$ and with the Ektachem $700(\bullet)$. Dotted line: see fig. 1. Evaluation by linear regression analysis. 


\section{Phosphate, inorganic}

Precision was obviously good. As a reference method is not yet available, accuracy control was performed by comparing the Ektachem results with methoddependent assigned values. The mean deviation was $+7.9 \%$ (range -7.6 to $+27.2 \%$ ) (tab. 6). Four out of 11 results did not fulfill the requirements of the guidelines $( \pm 15 \%)$. In a comparative study with native sera a positive bias was also observed (tab. 3), which was less marked $(+2.5 \%)$ but statistically significant. From the analysis of ultracentrifuged sera (fig. 7) and of native sera (fig. 8) of "normal" protein composition and from patients with gammopathies (not shown), it is evident that the Ektachem results are dependent on the protein concentration. At $120 \mathrm{~g} / 1$ protein ("normal" composition) the Ektachem results were $13.6 \%$ higher than those from the comparative method (SMA-C).

\section{Potassium}

The imprecision (tab. 1) was smaller than the allowable relative standard deviation (1). The results agreed well with the reference method values (mean deviation: $+1.2 \%$ (tab. 7)). At low concentrations, the results were higher, at high concentrations lower than the reference method value but never exceeding $\pm 8 \%$ (1). In a comparative study, no significant difference was observed between Ektachem and a field method for patient sera (tab. 3). From the analysis of ultracentrifuged sera (2) and native sera of "normal" pro-

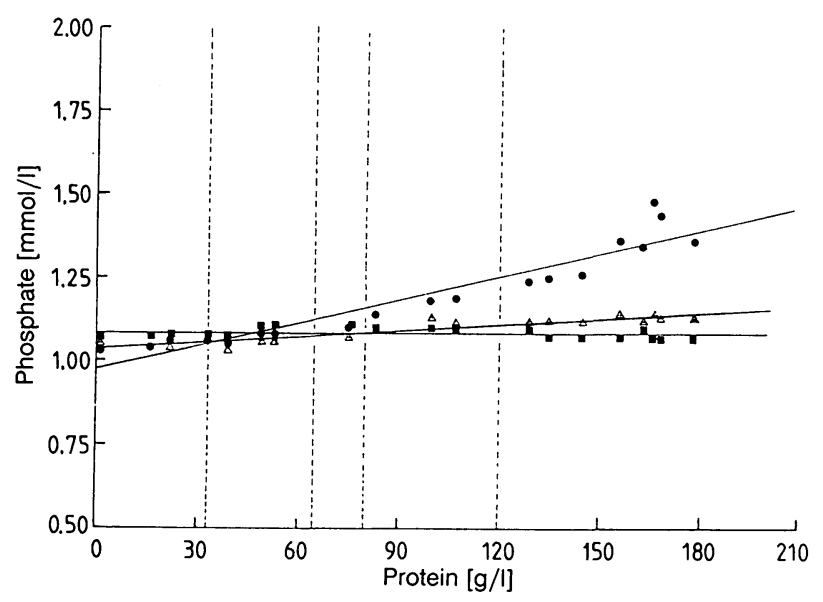

Fig. 7. Determination of phosphate in serum preparations $(\mathrm{pH}$ 7.40) of different protein concentrations (prepared by ultracentrifugation, see "Methods") by absorption spectrometry (phosphomolybdate SMA-C $\mathbf{m}$, molybdenum blue Hitachi $704 \triangle$ and with the Ektachem $700(\bullet)$. Dotted line: see fig. 1. Evaluation by linear regression analysis.
Tab. 6. Phosphate

\begin{tabular}{|c|c|c|c|}
\hline \multirow[t]{2}{*}{$\begin{array}{l}\text { Control } \\
\text { serum }\end{array}$} & \multicolumn{2}{|c|}{$\begin{array}{l}\text { Method-dependent } \\
\text { assigned value }\end{array}$} & \multirow[b]{2}{*}{$\left.d \%^{1}\right)$} \\
\hline & $\overline{\left.\bar{x}^{2}\right) \mathrm{mmol} / \mathrm{l}}$ & range $\mathrm{mmol} / \mathrm{l}$ & \\
\hline $\left.\mathrm{BC}^{3}\right)$ & 1.04 & $0.99-1.10$ & +5.8 \\
\hline $\left.\mathrm{BE}^{4}\right)$ & 1.2 & $1.1-1.4$ & +2.5 \\
\hline $\left.\mathrm{BK}^{5}\right)$ & 1.22 & 1.22 & +3.3 \\
\hline $\left.\mathrm{BA}^{6}\right)$ & 1.46 & $1.42-1.49$ & -5.8 \\
\hline $\left.\mathrm{BI}^{7}\right)$ & 1.50 & $1.48-1.55$ & +16.0 \\
\hline$\left.B G^{8}\right)$ & 1.80 & $1.74-1.97$ & +27.2 \\
\hline$\left(B F^{9}\right)$ & 1.85 & $1.5-2.1$ & -7.6 \\
\hline $\mathrm{BD}^{10}$ & 2.07 & $2.02-2.15$ & -2.4 \\
\hline $\left.\mathrm{BH}^{11}\right)$ & 2.26 & $2.20-2.42$ & +17.3 \\
\hline$\left.B J^{12}\right)$ & 2.35 & $2.26-2.42$ & +22.1 \\
\hline $\left.\mathrm{BB}^{13}\right)$ & 2.61 & $2.50-2.71$ & +8.2 \\
\hline
\end{tabular}

1) Deviation of the value obtained by Ektachem from the mean of the method-dependent assigned values $\bar{x}$.

$\left.{ }^{2}\right)$ Arithmetic mean of the contributing method-dependent assigned values.

3) Moni-trol I (Baxter Deutschland, Unterschleißheim, F. R. G.)

$\left.{ }^{4}\right)$ QCS Normal Control Serum Assayed (Ciba Corning, Fernwald, F. R. G.)

s) Pathonorm L (Merck, Darmstadt, F. R. G.)

6) Seronorm (Merck, Darmstadt, F. R. G.)

) Kontrollogen L (Behring, Frankfurt, F. R. G.)

$\left.{ }^{8}\right)$ Validate-N (Organon Teknika, Eppelheim, F. R. G.)

9) PED (Ciba Corning, Fernwald, F. R. G.)

${ }^{10}$ ) Moni-trol II (Baxter Deutschland, Unterschleißheim, F. R. G.)

11) Validate-A (Organon Teknika, Eppelheim, F. R. G.)

$\left.{ }^{12}\right)$ Kontrollogen LP (Behring, Frankfurt, F. R. G.)

$\left.{ }^{13}\right)$ Pathonorm H (Merck, Darmstadt, F. R. G.)

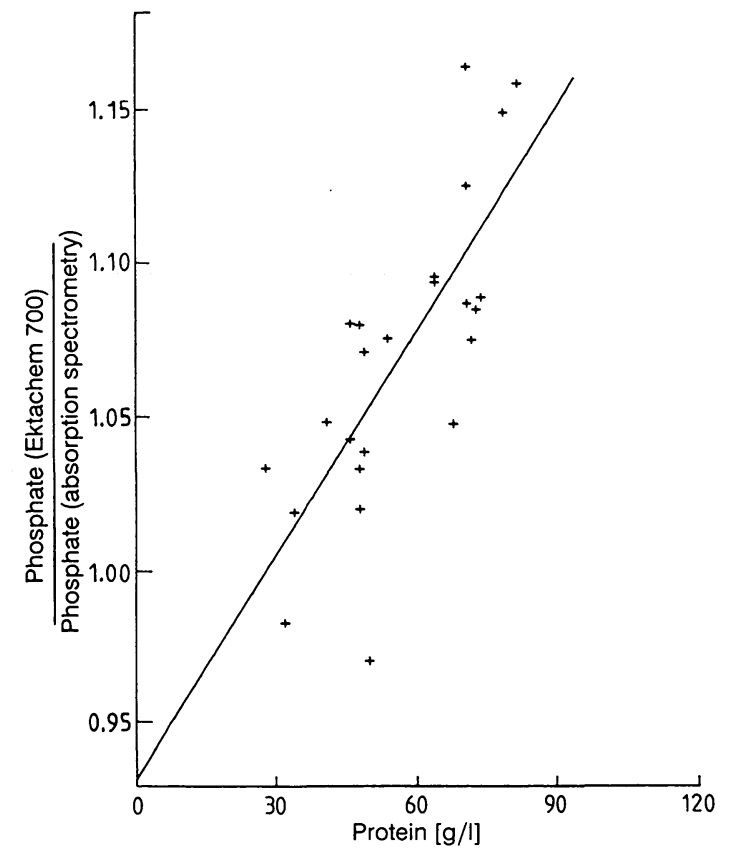

Fig. 8. Determination of phosphate in samples of native sera with the Ektachem 700 and by absorption spectrometry (SMA-C, see "Methods") in relation to the protein concentration $(n=24)$. Evaluation by linear regression analysis. 
Tab. 7. Potassium

\begin{tabular}{|c|c|c|}
\hline Control serum²) & $\begin{array}{l}\text { Reference } \\
\text { method value }{ }^{3} \text { ) } \\
\text { mmol/1 }\end{array}$ & $\left.d \%^{1}\right)$ \\
\hline A & 3.52 & +5.1 \\
\hline $\mathrm{C}$ & 4.56 & +0.9 \\
\hline $\mathrm{H}$ & 4.70 & +4.2 \\
\hline $\mathrm{K}$ & 4.72 & +5.9 \\
\hline E & 4.93 & -0.6 \\
\hline $\mathrm{D}$ & 4.94 & -0.8 \\
\hline B & 6.00 & -3.3 \\
\hline G & 6.37 & -0.3 \\
\hline $\mathrm{F}$ & 6.82 & -0.3 \\
\hline
\end{tabular}

1) Deviation of the value obtained by Ektachem from the reference method value in $\%$.

${ }^{2}$ ) Control serum A: SRM 909 (National Institute of Standards and Technology, Washington, D.C.).

$\mathrm{B}$ to $\mathrm{K}$ : not yet commercially available.

$\left.{ }^{3}\right)$ Reference method value as determined by the reference method (1. c. (9)).

tein composition (fig. 9), it can be concluded that the Ektachem results for potassium are similar to the results obtained by flame atomic emission spectrometry and "indirect" potentiometry at high protein concentrations. In samples from patients with multiple myeloma, the Ektachem results are higher $(+5 \%$ at $120 \mathrm{~g} / 1$ protein) and approach the values given by ion-selective electrodes (without predilution of the sample) (fig. 10).

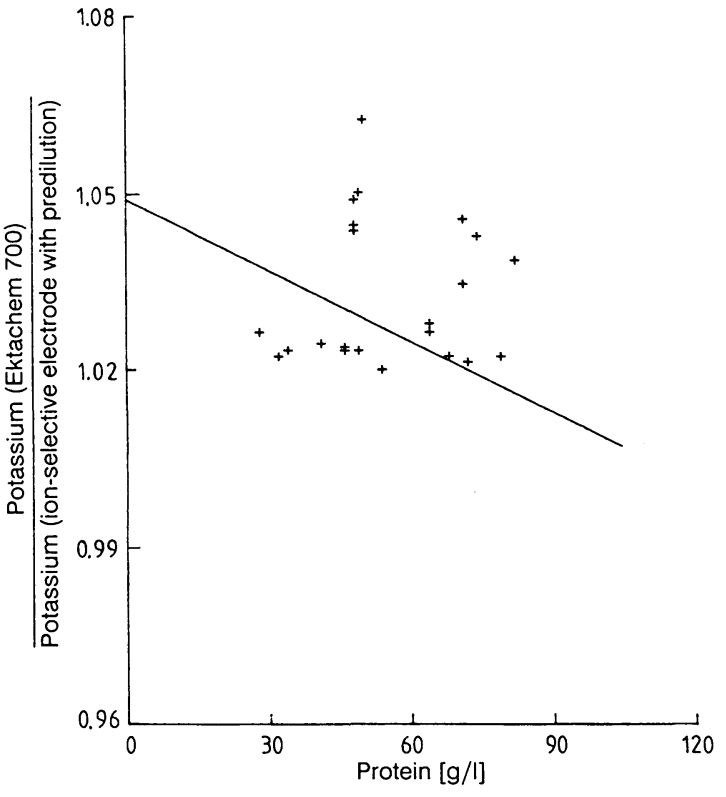

Fig. 9. Effect of protein concentration on the determination of potassium in samples of native sera with the Ektachem 700 and with an ion-selective electrode with predilution of the sample $(\mathrm{n}=24)$. Evaluation by linear regression analysis.
Tab. 8. Sodium

\begin{tabular}{lll}
\hline Control serum ${ }^{2}$ ) & $\begin{array}{l}\text { Reference } \\
\text { method value }\end{array}$ & $\left.\mathrm{d} \%^{1}\right)$ \\
mmol/1 & \\
\hline $\mathrm{K}$ & 120.4 & +10.5 \\
$\mathrm{H}$ & 120.6 & +11.9 \\
$\mathrm{~A}$ & 134.6 & +4.7 \\
$\mathrm{D}$ & 139.8 & +0.1 \\
$\mathrm{E}$ & 141.3 & -0.9 \\
$\mathrm{C}$ & 142.2 & +2.0 \\
$\mathrm{G}$ & 162.3 & +1.0 \\
$\mathrm{~B}$ & 162.9 & +0.1 \\
$\mathrm{~F}$ & 163.6 & +0.4 \\
\hline
\end{tabular}

1) Deviation of the value obtained by Ektachem from the reference method value in $\%$.

${ }^{2}$ ) Control serum A: SRM 909 (National Institute of Standards and Technology, Washington, D.C.).

$\mathrm{B}$ to $\mathrm{K}$ : not yet commercially available.

$\left.{ }^{3}\right)$ Reference method value as determined by the reference method (1.c. (10)).

\section{Sodium}

The imprecision (tab. 1) was well within the stringent limits of the guidelines $(\leq 2.0 \%)$ (1). The mean deviation from the reference method values was $+3.3 \%$ (allowable limit: $\pm 6 \%$ ) (tab. 8). The bias was mainly due to two control sera, for which the Ektachem results exceeded the reference method values by about $11 \%$. In a study of native sera, mean sodium values with the Ektachem were significantly $1.6 \mathrm{mmol} / \mathrm{l}$

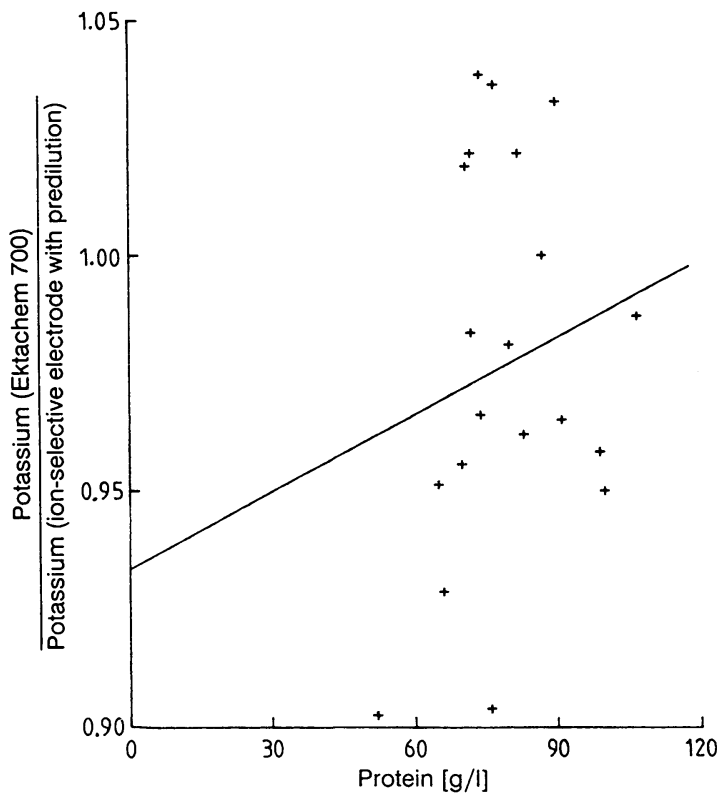

Fig. 10. Effect of protein concentration on the determination of potassium in samples of native paraproteinaemic sera with the Ektachem 700 and with an ion-selective electrode with predilution of the sample $(n=21)$. Evaluation by linear regression analysis. 
$(+1.2 \%)$ higher than the results from the comparative field method (tab. 3). Analyses of ultracentrifuged sera (2) and of sera of "normal" protein composition (fig. 11) show that the Ektachem results have a negative bias, compared with flame atomic emission spectrometry measurements and "indirect" potentiometry $(-3.0 \%)$. With paraproteins, a positive bias $(+6.9 \%$ at $120 \mathrm{~g} / 1$ protein) was obtained with ultracentrifuged sera, as well as with native sera (fig. 12).

\section{Discussion}

\section{Calcium}

The precision of the calcium determination was satisfactory with respect to the $3.3 \%$ limit of the guidelines (1). In accuracy control by reference method values a systematic negative bias was obvious, which may be due to interfering compounds of the matrix of the control sera. In the comparative study with native sera a negative bias was not observed.

\section{Chloride}

Chloride values with the Ektachem are dependent on the protein concentration of the sample. Due to the calibration procedure, good agreement is observed at "normal" protein concentrations with the field methods used to determine chloride in (total) serum; at high protein concentrations the Ektachem ion-selec-

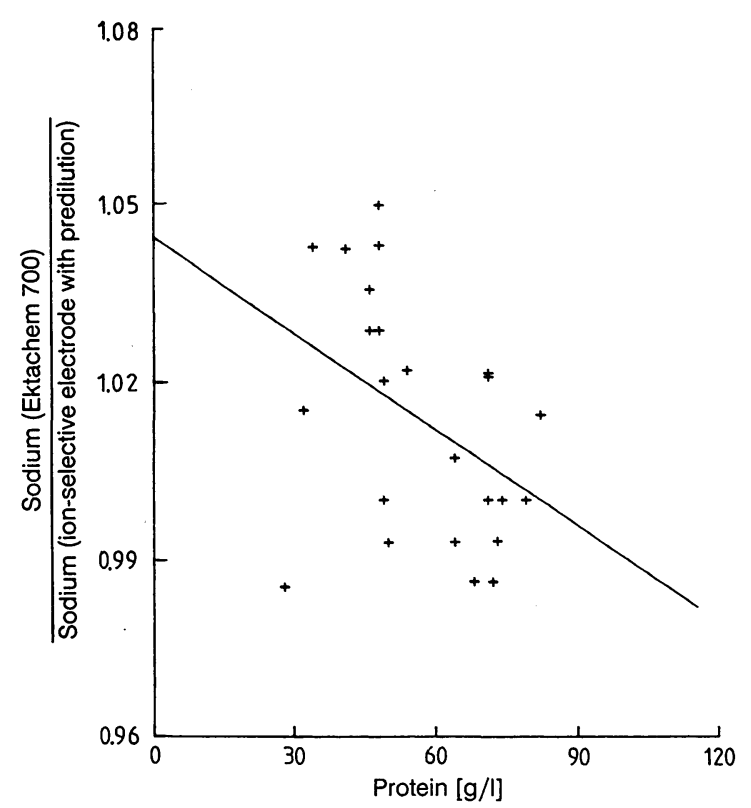

Fig. 11. Effect of protein concentration on the determination of sodium in samples of native sera with the Ektachem 700 and with an ion-selective electrode with predilution of the sample $(n=24)$. Evaluation by linear regression analysis. tive electrode values are higher. These differences are to be expected when determinations in serum water (Ektachem) are compared to determinations in total serum, which are dependent on the size of the macromolecules containing compartments devoid of electrolytes. "Normal" proteins and "paraproteins" did not behave in an obviously different manner in these experiments, which must be confirmed by using another "direct" ion-selective electrode analyzer. The low coefficient of correlation is due to the small range of contributing values.

\section{Magnesium}

All results obtained for control sera showed a negative bias with respect to the reference method value. This bias was also present in a comparative study with native sera. Probably the calibrator value must be reevaluated.

\section{Phosphate, inorganic}

Accuracy control is hampered by the lack of reference method values as well as adequate method-dependent assigned values for Ektachem. Nevertheless, a positive bias was found when the results were compared with the mean of the target values of control sera for field methods, and in a comparative study with native sera. Irrespective of the method used for comparison, the Ektachem phosphate values were clearly influenced by the protein concentration.

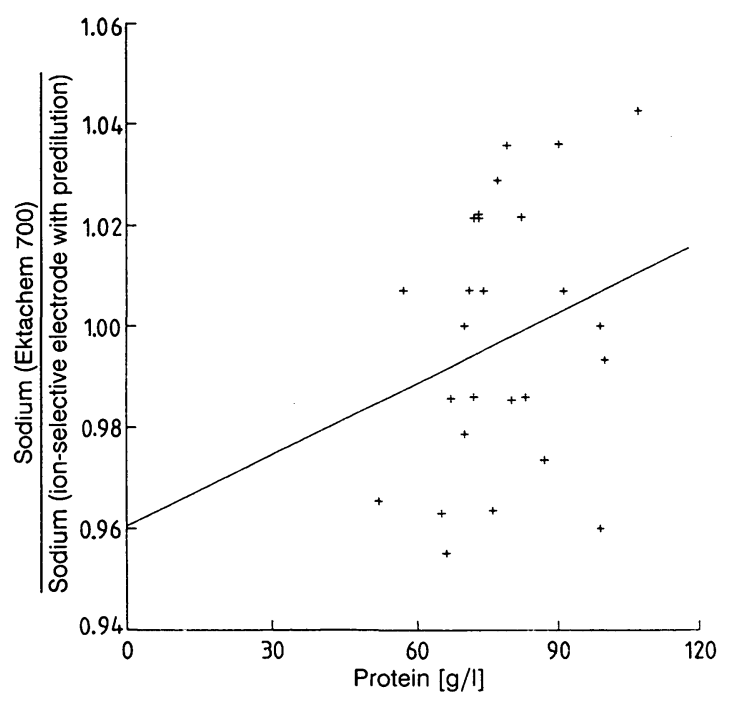

Fig. 12. Effect of protein concentration on the determination of sodium in samples of native paraproteinaemic sera with the Ektachem 700 and with an ion-selective electrode with predilution of the sample $(n=27)$. Evaluation by linear regression analysis. 


\section{Potassium}

Accuracy was adequate, even though at low concentrations there was a positive bias with respect to the reference method value and a negative bias at high concentrations. These characteristics were also observed, when reference method values were compared with values obtained by field methods of flame atomic emission spectrometry (3). The bias may be due to a slight unlinearity associated with the one-point calibration. The reason for the different response of the Ektachem to high "normal" and "paraproteinaemic" protein concentrations is unknown.

\section{Sodium}

Two out of nine reference method values were missed grossly by the Ektachem, a phenomenon sometimes encountered with ion-selective electrodes, due to interference by the matrix of the control serum. The influence of the protein concentration was similar to that observed for potassium analysis (2), and should be obviated by using another reference solution, GEN 04 (4), which was not available at the time. The coefficient of correlation is low, due to the narrow range of contributing values.

\section{References}

1. Anonymous (1988) Qualitätssicherung der quantitativen Bestimmungen im Laboratorium. Neue Richtlinien der Bundesärztekammer. Dt. Ärztebl. 85, B517-B532.

2. Külpmann, W. R. (1989) Influence of protein on the determination of sodium, potassium and chloride in serum by Ektachem DT 60 with the DTE module; evaluation with special attention to a possible protein error by flame atomic emission spectrometry and ion-selective electrodes; proposals to their calibration. J. Clin. Chem. Clin. Biochem. 27, $815-824$.

3. Külpmann, W. R., Lagemann, J., Sander, R. \& Maibaum, P. (1985) A comparison of reference method values for sodium, potassium and chloride with method-dependent assigned values. J. Clin. Chem. Clin. Biochem. 23, 865874.

4. Burnett, D., Ayers, G. J., Rumjen, S. C. \& Woods, T. F. (1988) Sodium measurements in the presence of paraproteins by four direct ISE methods and flame photometry compared. Ann. Clin. Biochem. 25, 102-109.

5. Brown, S. S., Healy, M. J. R. \& Kearns, M. (1981) Report on the Inter-Laboratory Trial of the Reference Method for the Determination of Total Calcium in Serum, Part I. J. Clin. Chem. Clin. Biochem. 19, 395-412.

6. Brown, S. S., Healy, M. J. R. \& Kearns, M. (1981) Report on the Inter-Laboratory Trial of the Reference Method for the Determination of Total Calcium in Serum, Part II. J. Clin. Chem. Clin. Biochem. 19, 413-426.
Ultracentrifugation seems to be suitable for preparing samples for the study of the influence of protein concentration. The results were always in good agreement with those for native sera of different protein concentration, but they were more conclusive, because the protein concentration could be determined over a wider range and the concentration of the pertinent analyte was less variable than in native sera. Results obtained with the Ektachem using hyperproteinaemic samples may deviate from those obtained with the other methods due to an increase in viscosity, which might change the time course of the Ektachem measurements. In accuracy control, similar results were usually obtained for native sera and control sera. This may be an indicator of the robustness of the Ektachem methods and their low susceptibility to interfering compounds. It enables the quality assessment of these carrier-bound reagents according to the new concept (11).

\section{Acknowledgement}

The work was supported by the Deutsche Gesellschaft für Klinische Chemie.
7. Velapoldi, R. A., Paule, R. C., Schaffer, R., Mandel, J., Murphy, T. J. \& Gramlich, J. W. (1979) Standard Reference Materials: A reference method for the determination of chloride in serum. NBS Spec. Public. 260-67.

8. Külpmann, W. R., Ruschke, D., Büttner, J. \& Paschen, K. (1989) A Candidate Reference Method for the Determination of Magnesium in Serum. J. Clin. Chem. Clin. Biochem. 27, 33-39.

9. Velapoldi, R. A., Paule, R. C., Schaffer, R., Mandel, J., Machlan, L. A. \& Gramlich, J. W. (1979) Standard Reference Materials: A reference method for the determination of potassium in serum. NBS Spec. Public. 260-63.

10. Velapoldi, R. A., Paule, R. C., Schaffer, R., Mandel, J. \& Moody, J. R. (1978) Standard Reference Materials: A reference method for the determination of sodium in serum. NBS Spec. Public. 260-60.

11. Stamm, D. (1982) A New Concept for Quality Control of Clinical Laboratory Investigations in the Light of Clinical Requirements and Based on Reference Method Values. J. Clin. Chem. Clin. Biochem. 20, 817-824.

12. Danninger, J., Spanbeek, M. \& Spaethe, R. (1983) Bestimmung von anorganischem Phosphat in Patientenseren mit einer modifizierten Molybdat-Reaktion. Ärztl. Lab. 29, $335-338$.

Prof. Dr. W. R. Külpmann Institut für Klinische Chemie I Medizinische Hochschule Hannover Konstanty-Gutschow-Straße 8

D-3000 Hannover 61 


.

